\title{
Cumulate origin for Isua dunites rules out formation as an Eoarchaean ophiolite
}

\author{
PEDRO WATERTON ${ }^{1}$, JUAN MIGUEL GUOTANA ${ }^{2}$, \\ IKUYA NISHIO $^{2}$, TOMOAKI MORISHITA ${ }^{2}$, KENICHIRO \\ TANI $^{3}$, SARAH WOODLAND ${ }^{4}$, HÉLĖNE LEGROS ${ }^{4}$, D. \\ GRAHAM PEARSON $^{4}$ AND KRISTOFFER SZILAS ${ }^{1}$ \\ ${ }^{1}$ University of Copenhagen \\ ${ }^{2}$ Kanazawa University \\ ${ }^{3}$ National Museum of Nature and Science \\ ${ }^{4}$ University of Alberta \\ Presenting Author: pw@ign.ku.dk
}

Ophiolites present primary evidence for the existence of oceanic lithosphere and the operation of oceanic ridges deep in Earth's history. The oldest widely accepted ophiolites formed in the Palaeoproterozoic and have been interpreted as evidence for the operation of some form of plate tectonics at that time, though the existence of Archaean ophiolites is controversial [1,2]. Dunite lenses from the 3.7-3.8 Ga Isua Supracrustal Belt (ISB), North Atlantic Craton, Greenland, have been previously interpreted as depleted mantle wedge residues, complementary to arc-like volcanic rocks in the supracrustal sequence. This would place the ISB dunites among Earth's oldest mantle samples, and has been used to argue that the ISB represents the oldest known ophiolite [3]. We present new platinum-group element (PGE) and Re-Os isotopic data for the ISB dunites, and critically assess the evidence that they are mantle residues. We find no solid evidence in support of a mantle origin. Instead, signatures of chromite and Os-Ir alloy fractionation, consistent $\mathrm{Pt}$ and $\mathrm{Pd}$ depletion, elevated $\mathrm{Ni}$ contents, and trace element systematics indicate that the dunites formed as olivine \pm chromite cumulates with varying amounts of intercumulus melt. Their compositions are consistent with crystallisation from magmas represented by ISB volcanic rocks, and Re-Os model ages overlap the $\sim 3720 \mathrm{Ma}$ age of the volcanic sequence, suggesting the dunites represent magma chambers or conduits that fed the volcanism. There are no mantle residues in the ISB and the belt lacks a sheeted dyke complex [4]. The ISB is not an ophiolite and that there are no known Eoarchaean ophiolites.

1. Condie, K. A planet in transition: The onset of plate tectonics on Earth between 3 and 2 Ga? Geosci. Front. 9 , 51-60 (2018).

2. Palin, R. et al. Secular change and the onset of plate tectonics on Earth. Earth-Science Rev. 207, 103172 (2020).

3. Friend, C. \& Nutman, A. Dunites from Isua, Greenland: A ca. 3720 Ma window into subcrustal metasomatism of depleted mantle. Geology 39, 663-666 (2011).

4. Nutman, A. \& Friend, C. Comment on 'A vestige of earth’s oldest ophiolite’. Science. 318, 746 (2007). 